\title{
KONSEP DAN PERBANDINGAN BUY NOW, PAY LATER DENGAN KREDIT PERBANKAN DI INDONESIA: SEBUAH KENISCAYAAN DI ERA DIGITAL DAN TEKNOLOGI
}

(Buy Now, Pay Later's Concept and Comparison with Banking Credits in Indonesia: An Inevitability In Digital And Technology Era)

\author{
Bayu Novendra \\ Fakultas Hukum Universitas Indonesia \\ Jl. Prof. Mr Djokosoetono, Kota Depok, Jawa Barat 16424 \\ e-mail: bayunovendra5@gmail.com \\ Sarah Safira Aulianisa \\ Fakultas Hukum Universitas Indonesia \\ Jl. Prof. Mr Djokosoetono, Kota Depok, Jawa Barat 16424 \\ e-mail: sarhsafira@gmail.com
}

Naskah diterima: 28 April 2020; revisi: 15 Juli 2020; disetujui: 22 Juli 2020

\begin{abstract}
Abstrak
Perkembangan teknologi informasi dan komunikasi telah memberikan dampak yang signifikan dalam berbagai aspek kehidupan di era digital, tidak terkecuali pada sektor keuangan atau finansial. Salah satunya adalah penerapan teknologi informasi di bidang keuangan yang umumnya disebut sebagai financial technology (fintech). Bagi sektor keuangan, inovasi teknologi sebenarnya bukan merupakan fenomena baru. Sehingga, secara inheren financial technology juga bukan merupakan pengembangan baru bagi industri jasa keuangan. Melalui metode yuridis normatif, akan dianalisis skema pembayaran dengan istilah Buy Now, Pay Later (BNPL) sebagai fasilitas keuangan yang memungkinkan metode pembayaran dengan cicilan tanpa kartu kredit. Metode BNPL yang seperti itu menunjukkan kemiripan dan kesamaan dengan unsur-unsur dasar kredit perbankan seperti kepercayaan, jangka waktu, tingkat risiko, dan prestasi dalam bentuk kredit. Namun kesamaan tersebut ternyata tidak diimbangi dengan kesamaan menerapkan prinsip kehati-hatian dalam regulasi BNPL di Indonesia saat ini. Hal ini kemudian yang membuka celah akan berbagai potential issues dari mekanisme skema pembayaran BNPL.

Kata Kunci: buy now pay later, fintech, kredit perbankan
\end{abstract}

\begin{abstract}
The development of information and communication technology has had a significant impact in various aspects of life in the digital age, including the financial or financial sector. One of them is the application of information technology in finance which is generally referred to as financial technology (fintech). For the financial sector, technological innovation is actually not a new phenomenon. So, inherently financial technology is also not a new development for the financial services industry. Through the normative juridical method, payment schemes will be analyzed using the term Buy Now, Pay Later (BNPL) as a financial facility that allows payment methods with installments without a credit card. Such BNPL methods show similarities and similarities with the basic elements of bank credit such as trust, time period, level of risk, and achievement in the form of credit. However, this similarity was not balanced with the similarity in applying the precautionary principle in the current BNPL regulation in Indonesia. This then opens the gaps for various potential issues of the BNPL payment scheme mechanism.
\end{abstract}

Keywords: buy now pay later, fintech, banking credit 


\section{A. Pendahuluan}

Perkembangan teknologi informasi dan komunikasi telah memberikan dampak yang signifikan dalam berbagai aspek kehidupan di era digital, tidak terkecuali pada sektor keuangan atau finansial. Sektor ini memiliki peran penting dalam perekonomian dan akan terus mengalami perkembangan seiring dengan kebutuhan masyarakat. Salah satunya adalah penerapan teknologi informasi di bidang keuangan yang umumnya disebut sebagai financial technology (fintech). Fintech merupakan salah satu bentuk penerapan teknologi informasi di bidang keuangan yang pertama kali muncul di tahun 2004 oleh Zopa, suatu institusi keuangan di Inggris yang menjalankan jasa peminjaman uang, yang dewasa ini sudah merambah ke berbagai macam jenis aplikasi untuk berbagai macam jenis transaksi. ${ }^{1}$

Penyesuaian sektor finansial dengan perkembangan teknologi dalam bentuk fintech tidak hanya terjadi di negara maju, tetapi juga tumbuh dengan pesat di negara berkembang seperti Indonesia dan negaranegara di Asia Tenggara. Fintech dalam pemahaman sederhana merupakan gabungan antara layanan jasa keuangan dengan pemanfaatan teknologi, yang mengubah model bisnis konvensional menjadi modern, dalam hal ini proses bisnis yang dilakukan oleh pelaku industri menjadi lebih efisien, ekonomis, bahkan minim interaksi manusia. ${ }^{2}$ Keberadaan fintech diharapkan dapat mendatangkan proses transaksi keuangan yang lebih praktis dan aman yang meliputi pembayaran, peminjaman uang, transfer, ataupun jual beli saham.

Perkembangan fintech di Indonesia sejalan dengan berkembangnya penggunaan telepon seluler dan layanan internet, hingga ditandai dengan terbentuknya Asosiasi Fintech Indonesia yang telah terdaftar secara sah sebagai badan hukum sejak 10 Maret 2016. ${ }^{3}$ Keanggotaan Asosiasi Fintech Indonesia terdiri atas perusahaan fintech, perusahaan keuangan, ataupun kelembagaan lain yang memiliki keahlian dan ketertarikan di bidang teknologi keuangan. Penyedia layanan keuangan mengembangkan teknologi yang dapat mendisrupsi pasar keuangan tradisional dengan mengembangkan aplikasi baru yang dapat digunakan mulai untuk pembayaran hingga aplikasi yang lebih kompleks untuk artificial intelligence dan big data. ${ }^{4}$ Secara umum, aktivitas-aktivitas fintech dalam layanan jasa keuangan dapat diklasifikasikan ke dalam 5 (lima) kategori, yaitu sebagai berikut: ${ }^{5}$

1. Pembayaran, transfer, kliring, dan penyelesaian (payment, clearing and settlement). Aktivitas ini terkait erat dengan pembayaran mobile (baik oleh bank atau lembaga keuangan non-bank), dompet 
elektronik (digital wallet), mata uang digital (digital currencies) dan penggunaan teknologi buku besar terdistribusi (distributed ledger technology, DLT) untuk infrastruktur pembayaran. Modelmodel ini bertujuan untuk meningkatkan inklusi keuangan (financial inclusion) dan memastikan akses konsumen yang lebih besar pada layanan jasa pembayaran serta memastikan berfungsinya sistem pembayaran dengan baik. Model ini juga dapat berkontribusi pada pengelolaan sejumlah besar transaksi serta transfer dan settlements besar antar lembaga keuangan.

2. Deposito, pinjaman dan penambahan modal (deposits, lending and capital raising). Inovasi fintech yang paling umum di bidang ini adalah crowdfunding dan platform pinjaman P2P (peer-to-peer) secara online, mata uang digital (digital currencies) dan DLT. Aplikasi ini terkait erat dengan intermediasi keuangan.

3. Manajemen risiko (risk management). Perusahaan fintech yang berpartisipasi di sektor asuransi (InsurTech) berpotensi mempengaruhi tidak hanya pemasaran dan distribusi asuransi, melainkan juga underwriting, penetapan harga risiko dan klaim penyelesaian. Manajemen risiko juga memperhatikan komitmen dan registrasi jaminan dan penjaminan dalam operasi kredit.

4. Dukungan pasar (market support). Bagian teknologi fintech yang dapat menyediakan proses yang lebih sederhana atau lebih efisien, seperti e-aggregators, big data, verifikasi ID secara digital, penyimpanan data dan pemrosesan (cloud computing), atau pelaksanaan perintah melalui kontrak "pintar" (smart contracts). Akses dan kontestabilitas informasi merupakan isu penting di sini.

5. Manajemen investasi (investment management). Dimensi ini mencakup platform e-trading yang memungkinkan konsumen untuk berinvestasi secara langsung melalui komputer pada semua jenis aset, kontrak "pintar" (smart contracts), dan inovasi fintech yang menawarkan saran otomatis mengenai layanan keuangan, termasuk manajemen investasi dan portofolio.

Secara garis besar, keberadaan fintech mencatat pencapaian positif di kategori online lending (pinjaman online). Merujuk pada data Otoritas Jasa Keuangan, fintech kategori peer to peer lending yang hingga Februari 2020 jumlahnya telah mencapai 161 perusahaan ini berhasil mencatatkan total akumulasi pinjaman sebesar Rp. 41,04 triliun. ${ }^{6}$ Pertumbuhan ini bahkan melampaui kinerja perbankan konvesional di Indonesia. Pesatnya pertumbuhan online lending (pinjaman online) juga meningkatnya investor pasar modal di Indonesia merupakan sebuah gambaran bagaimana fintech yang mendapatkan respon positif di masyarakat bisa berdampak pada peningkatan inklusi keuangan di Indonesia. Melalui fintech, produk jasa keuangan bisa menjangkau masyarakat secara lebih luas dengan biaya operasional yang rendah. 
Bagi sektor keuangan inovasi teknologi sebenarnya bukan merupakan fenomena baru. Secara inheren fintech juga bukan merupakan pengembangan baru bagi industri jasa keuangan. Meskipun demikian, intensitas pembahasannya masih tetap menjadi perhatian banyak pihak, baik di kalangan pengambil keputusan, akademisi, dan praktisi bisnis keuangan maupun di tingkat publik sebagai konsumen atau pengguna fintech. Dalam konteks ini, telah dikenal pula skema pembayaran dengan istilah Buy Now, Pay Later (selanjutnya disingkat BNPL) sebagai fasilitas keuangan yang memungkinkan metode pembayaran dengan cicilan tanpa kartu kredit, yang sekilas mirip dengan sistem kredit pada perbankan konvensional. Berkembangnya fintech yang sejalan dengan akses keuangan digital yang semakin terbuka lebar memiliki potensi besar untuk turut meningkatkan akses masyarakat terhadap sektor keuangan. Hal ini sekaligus membuka celah akan berbagai potential issues pada pasar keuangan dan institusi serta penyediaan layanan keuangan yang berkembang sebagai dampak dari adanya model bisnis, aplikasi, proses, dan produk baru dalam jasa keuangan.

Berdasarkan hal-hal tersebut, maka tulisan ini bertujuan untuk melakukan tinjauan terhadap BNPL sebagai skema pembayaran baru di era digital, kemudian melakukan studi komparasi antara sistem kredit pada perbankan konvensional dengan skema pembayaran Pay Later pada salah satu fintech, serta menganalisa potential issues terkait risiko hukum dan risiko keuangan baik terhadap perusahaan maupun masyarakat dalam implementasinya di Indonesia.

\section{B. Metode Penelitian}

Dalam tulisan ini, penulis melakukan penelitian yuridis-normatif untuk menganalisis skema pembayaran dengan istilah BNPL sebagai fasilitas keuangan yang memungkinkan metode pembayaran dengan cicilan tanpa kartu kredit. Penelitian normatif atau biasa dikenal dengan penelitian hukum doktrinal dilakukan dengan cara meneliti bahan pustaka atau data sekunder. ${ }^{7}$ Sesuai dengan sifat dari jenis penelitian yang dipilih, dalam memperoleh data, Penulis melakukan studi kepustakaan dengan mengumpulkan serta mempelajari bahan hukum primer dan sekunder yang berupa buku, artikel, hasil penelitian, dan peraturan perundang-undangan yang relevan dengan objek penelitian. Bahan-bahan pustaka yang dipilih kemudian digunakan sebagai landasan berpikir dari analisis yang dibuat. Analisis data dilakukan secara deskriptif kualitatif untuk menjawab rumusan masalah dalam penelitian ini

\section{Pembahasan}

\section{Buy Now, Pay Later sebagai Skema Pembayaran Baru di Era Ekonomi Digital}

Fintech merupakan lembaga intermediasi keuangan yang salah satu fungsinya yakni menjadi perantara bagi para pelaku transaksi keuangan yang tidak ingin bekerja sama

Soedjono Soekanto dan Sri Mamudji, Penelitian Hukum Normatif: Suatu Tinjauan Singkat, (Jakarta: Raja Grafindo Persada, 1994), hlm. 13 
dengan pihak perbankan karena merasa diberatkan. $^{8}$ Dalam perkembangannya, berbagai market place atau tempat transaksi ekonomi secara online telah banyak memberikan berbagai bentuk pelayanan yang di bidang keuangan. Transaksi ekonomi yang dilakukan melalui fintech kemudian menciptakan beberapa metode pemasaran sekaligus menciptakan skema pembayaran baru yang lebih praktis dan modern, dengan tujuan untuk memberikan kemudahan serta menarik konsumen. Layanan yang dilakukan meliputi payment channel system, digital banking, online digital insurance, Peer to Peer $(P 2 P)$ Lending serta layanan crowd funding. ${ }^{9}$

Saat ini, BNPL atau lebih familiar dikenal sebagai Pay Later, tengah menjadi opsi skema pembayaran yang menarik bagi masyarakat yang memiliki anggaran terbatas. BNPL adalah fasilitas keuangan yang memungkinkan metode pembayaran dengan cicilan tanpa kartu kredit. ${ }^{10}$ Pay Later merupakan layanan pinjaman online tanpa kartu kredit yang memungkinkan konsumen membayar suatu transaksi di kemudian hari, baik dengan sekali bayar atau dengan mencicil. Fasilitas pinjaman ini juga sering disebut dengan istilah credit limit. ${ }^{11}$ Metode baru ini mulai menjadi salah satu opsi pembayaran digital selain kartu kredit/debit serta metode transfer mobile, ketika kebutuhan akan cicilan kredit online kian dibutuhkan oleh masyarakat.

Berbagai fintech sebagai platform penyedia layanan keuangan online, situs belanja daring hingga layanan dompet digital menawarkan diversifikasi produk ke ranah pembiayaan kredit. Hingga kini, beragam jenis e-commerce telah menggandeng fintech untuk pengajuan pinjaman. Sebut saja dompet digital GoPay yang menyediakan fitur PayLater. Begitu pula dengan OVO melalui OVO PayLater. Hal senada juga dilakukan oleh berbagai perusahaan, market place atau e-commerce seperti Traveloka, Bukalapak, Akulaku, Shopee, Kredivo dan banyak platform digital lainnya yang telah memberikan fasilitas Pay Later kepada para penggunanya. Perusahaan fintech yang memiliki layanan pembayaran dengan skema BNPL, mendapatkan keuntungan dari biaya ketelambatan pembayaran (late fees), biaya penyimpanan akun (account-keeping fees) setiap bulannya, dan biaya pemrosesan (processing fee) untuk setiap pembayaran yang dilakukan oleh Pengguna. ${ }^{12}$

Pemerintah melalui Bank Indonesia, merespon perkembangan fintech secara berimbang, baik dalam mendorong inovasi maupun menjaga stabilitas perekonomian di Indonesia. Hal ini secara umum diatur melalui Peraturan Bank Indonesia Nomor

8 Marcin Kotarba, "New Factors Inducing Inducing Changes in the Retail Banking Customer Relationship Management (CRM) and Their Exploration by the Fintech Industry", Foundations of Management Journal Vol. 8 (2016): 8.

9 Immanuel Adhitya Wulanata Chrismantianto, "Analisis SWOT Implementasi Teknologi Finansial Terhadap Kualitas Layanan Perbankan di Indonesia", Jurnal Ekonomi dan Bisnis Vol. 20 No. 1 (2017): 134.

10 Bina Nusantara University Popular Articles, "Apa itu PayLater?," Bina Nusantara University, https://sis.binus. ac.id/2020/01/30/apa-itu-paylater/ (diakses 27 April 2020).

11 Cigna Health \& Wellness, "Waspadai Skema Pay Later Yang Malah Menjadi Pain Later," Cigna, https://www.cigna. co.id/health-wellness/waspada-skema-pay-later (diakses 27 April 2020).

12 Debt Busters, "The Truth About Buy Now Pay Later Schemes," https://debtbusters.com.au/blog/what are-buynow-pay-later-schemes/ (diakses 27 April 2020). 
19/12/PBI/2017 tentang Penyelenggaraan Teknologi Finansial (PBI No. 19/2017), serta dua peraturan turunannya yaitu Peraturan Anggota Dewan Gubenur Nomor 19/14/ PADG/2017 (PADG No. 19/14/2017) tentang Ruang Uji Coba Terbatas (Regulatory Sandbox) Teknologi Finansial dan Peraturan Anggota Dewan Gubenur Nomor 19/15/PADG/2017 (PADG No. 19/15/2017) tentang Tata Cara Pendaftaran, Penyampaian Informasi dan Pemantauan Penyelenggaraan Teknologi Finansial. Salah satu poin penting yang tertuang dalam peraturan tersebut adalah ditetapkannya kewajiban para penyelenggara fintech di bidang jasa sistem pembayaran keuangan untuk melakukan pendaftaran kepada Bank Indonesia. Selain itu, para penyelenggara diwajibkan untuk melakukan uji coba terbatas atas produk layanan teknologi dan/model bisnis keuangannya dalam regulatory sandbox. Pendekatan regulatory sandbox ini akan membantu regulator memahami risiko yang mungkin muncul jika suatu produk fintech digunakan secara luas, namun berada dalam lingkungan yang terkendali. Ini akan membantu para penyelenggara fintech, terutama perusahaan pemula (start-up), untuk menguji produk tanpa harus menanggung biaya penuh regulasi atau menghadapi tindakan penegakan hukum.

Selain itu, Otoritas Jasa Keuangan sebagai lembaga pengawas, secara khusus mengatur mengenai fintech peer to peer lending melalui Peraturan Otoritas Jasa Keuangan Nomor 77/POJK.01/2016 tentang Layanan Pinjam Meminjam Uang Berbasis Teknologi Informasi (POJK No. 77/2016). POJK ini menjadi bukti awal adanya proporsi khusus untuk regulasi jasa keuangan di Indonesia. Selain ditujukan untuk melindungi kepentingan konsumen terkait keamanan dana dan data, POJK tersebut juga bertujuan untuk melindungi kepentingan nasional terkait dengan pencegahan kegiatan pencucian uang (money laundering), pendanaan terorisme, dan stabilitas sistem keuangan.

POJK No. 77/2016 mendefinisikan Pemberi Pinjaman sebagai orang, badan hukum, dan/atau badan usaha, yang dapat berasal dari dalam dan/atau luar negeri, yang mempunyai piutang karena perjanjian Layanan Pinjam Meminjam Uang Berbasis Teknologi Informasi. ${ }^{13}$ Sedangkan, Penerima Pinjaman adalah orang perseorangan WNI dan/atau badan hukum Indonesia yang mempunyai utang karena perjanjian Layanan Pinjam Meminjam Uang Berbasis Teknologi Informasi. ${ }^{14}$ Selanjutnya, Pasal 1 angka 6 POJK No. 77/2016 menyebutkan bahwa Penyelenggara Layanan Pinjam Meminjam Uang Berbasis Teknologi Informasi (Penyelenggara) adalah badan hukum Indonesia yang menyediakan, mengelola, dan mengoperasikan Layanan Pinjam Meminjam Uang Berbasis Teknologi Informasi. Penyelenggara menyediakan, mengelola, dan mengoperasikan Layanan Pinjam Meminjam Uang Berbasis Teknologi Informasi dari pihak Pemberi Pinjaman kepada pihak Penerima Pinjaman yang sumber dananya berasal dari pihak Pemberi Pinjaman. Adapun, perjanjian peer to peer lending yang dimaksud, meliputi perjanjian antara Penyelenggara dengan Pemberi Pinjaman dan perjanjian 
antara Pemberi Pinjaman dengan Penerima Pinjaman. ${ }^{15}$

Apabila ditinjau dari aspek hukum perjanjian, terdapat tiga pihak yang terlibat dalam perjanjian pinjaman dengan skema Pay Later. Para pihak tersebut merupakan subyek hukum yang memiliki hak dan kewajiban, secara umum yaitu:

a) Konsumen selaku Penerima Pinjaman, yaitu mereka yang berminat membeli barang atau jasa, namun memiliki keterbatasan dalam melakukan pembelian atau pembayaran secara tunai. Jika konsumen tersebut akhirnya membeli barang atau jasa dengan fasilitas Pay Later, maka ia akan menjadi Debitur. Debitur memiliki kewajiban untuk memenuhi perikatan secara tepat waktu dan sewajarnya. Hal ini berkaitan dengan kemampuan membayar dan melaksanakan prestasi yang diperjanjikan. Oleh karena itu, dalam suatu perjanjian pinjaman dengan skema Pay Later, kemampuan membayar tetap harus menjadi perhatian untuk memperkecil risiko dalam perjanjian kredit.

b) Penyedia layanan Pay Later selaku Pemberi Pinjaman, dalam hal ini yaitu perusahaan atau situs daring yang menawarkan barang atau jasa seperti dengan fasilitas pembayaran melalui skema Pay Later. Sehingga, penyedia layanan ini dengan kata lain merupakan Kreditur.

c) Fintech selaku Penyelenggara Layanan Pinjam Meminjam Uang Berbasis Teknologi Informasi, yaitu pihak yang menyalurkan pinjaman dan akan menagih pinjaman. Fintech ini juga yang akan menentukan seberapa besar fasilitas serta berbagai ketentuan pinjam-meminjam lainnya yang bisa didapatkan oleh calon Debitur (konsumen). Dalam hal ini, fintech tersebut merupakan peer to peer lending sebagai penyelenggara layanan jasa keuangan untuk mempertemukan Pemberi Pinjaman dengan Penerima Pinjaman dalam rangka melakukan perjanjian pinjam meminjam melalui sistem elektronik. dengan menggunakan jaringan internet. ${ }^{16}$

Sebagai suatu subyek hukum, fintech berkedudukan sebagai Penerima Kuasa dan Wewenang dari Pemberi Pinjaman atas Perjanjian Pinjaman yang terjadi antara Penerima Pinjaman dengan Pemberi Pinjaman berdasarkan Perjanjian Penyelenggaraan Layanan Pinjam Meminjam Uang Berbasis Teknologi Informasi yang dibuat dan ditandatangani oleh dan antara Penyelenggara dan Pemberi Pinjaman. Dimana berdasarkan perjanjian Penyelenggaraan tersebut, Penyelenggara diberikan kuasa dan wewenang antara lain untuk menandatangani dan melaksanakan perjanjian pemberian pinjaman antara Pemberi Pinjaman dan Penerima Pinjaman yang telah memenuhi syarat-syarat dan ketentuan-ketentuan yang ditetapkan oleh Penyelenggara.

Untuk mendukung analisis dan pembahasan pada sub-bab berikutnya, Penulis akan memberikan contoh spesifik dari salah satu Penyelenggara skema pembayaran Buy Now, Pay Later di Indonesia yaitu OVO PayLater. OVO PayLater adalah layanan pinjaman yang 
diberikan oleh perusahaan Peer-to-Peer Lending PT Indonusa Bara Sejahtera (Taralite) dalam bentuk kredit limit yang dapat digunakan untuk bertransaksi pada aplikasi OVO. PT Indonusa Bara Sejahtera ("Taralite") selaku pihak OVO Paylater, telah terdaftar di Otoritas Jasa Keuangan ("OJK") sejak tanggal 21 Juli 2017 sebagai Penyelenggara Layanan Pinjam Meminjam Uang Berbasis Teknologi Informasi dengan Surat Tanda Bukti Terdaftar dari OJK Nomor S-622/NB.11/2017 sehingga pelaksanaan kegiatan usaha Taralite telah diawasi secara ketat oleh OJK berdasarkan Peraturan Otoritas Jasa Keuangan Nomor 77/POJK.01/2016 tentang Layanan Pinjam Meminjam Uang Berbasis Teknologi Informasi. ${ }^{17}$ Adapun, mekanisme pembayaran pada OVO PayLater diselenggarakan dengan cara kerja sebagai berikut: ${ }^{18}$

a) Subyek yang akan mendapatkan fasilitas OVO Paylater adalah pengguna rutin aplikasi OVO dengan umur akun minimal 60 (enam puluh) hari dan telah menjadi anggota OVO Premier;

b) Syarat untuk mendapatkan fasilitas OVO Paylater yakni dengan mengisi informasi pribadi, menyetujui syarat dan ketentuan, memberikan foto Kartu Tanda Penduduk (E-KTP) dan menyetujui perjanjian fasilitas pinjaman dengan partner OVO (terlampir di Syarat dan Ketentuan);

c) Proses pengajuan aplikasi OVO PayLater tersebut maksimal 1×24 jam, kemudian akan diberikan notifikasi pada aplikasi OVO apabila telah selesai diproses. Hasil pengajuan merupakan sepenuhnya hak dari Partner (PT Indonusa Bara Sejahtera);

d) Kepemilikan OVO PayLater tidak dapat dipindahtangankan dari pemilik sah yang identitasnya didaftarkan pada saat pengajuan aplikasi, dengan alasan apapun; ${ }^{19}$

e) OVO PayLater tidak memiliki batas minimum transaksi;

f) Notifikasi tagihan akan diberikan pada tanggal 27 setiap bulannya yang harus dibayarkan paling lambat tanggal 1 di bulan berikutnya. Transaksi OVO PayLater pada tanggal 27 sampai 26 bulan berikutnya, akan ditagih pada tanggal 27 bulan berikutnya;

g) Setelah jatuh tempo, semua tagihan yang belum terbayar akan dikenakan bunga sisa tagihan sebesar $0,1 \%$ setiap harinya dan akan ditagih pada tagihan berikutnya;

h) Akun OVO PayLater akan dibekukan jika Penerima Layanan tidak melunasi atau melakukan pembayaran seluruh jumlah tagihan jika melewati batas jatuh tempo. Partner berhak mengambil tindakan hukum lainnya berdasarkan perjanjian fasilitas pinjaman.

\section{Komparasi Skema Pembayaran Buy Now, Pay Later dengan Sistem Kredit Perbankan Konvensional}

\section{a. Sistem Kredit Bank Konvensional}

Kata kredit berasal dari bahasa Yunani yaitu kata redere yang berarti kepercayaan, ${ }^{20}$ sedangkan dari bahasa Romawi kata kredit

Taralite, "Disclaimer Risiko", https://www.taralite.com/assets/documents/disclaimer.pdf (diakses 27 April 2020).

18 OVO, "OVO Help Center", https://www.ovo.id/helpcenter/article/360028038351 (diakses 27 April 2020).

19 OVO, "OVO Help Center", https://www.ovo.id/helpcenter/article/360028038891 (27 April 2020).

20 Thomas Suyatno, et al., Dasar-dasar Perkreditan, Edisi ketiga, (Jakarta: PT. Gramedia Pustaka Utama, 1994), hlm 15. 
merupakan credere artinya percaya. ${ }^{21}$ Dalam arti luas, kredit dapat diartikan sebagai pinjaman yang didasarkan pada komponenkomponen kepercayaan, risiko, dan pertukaran ekonomi dimasa mendatang. ${ }^{22} \mathrm{Hal}$ ini berarti Esensialitas dari kredit adalah pinjaman yang diberikan atas dasar kepercayaan dari kreditur kepada debitur bahwa kredit yang diberikannya akan dikembalikan oleh debitur dikemudian hari.

Dalam Pasal 1 Angka 11 Undang-Undang Nomor 10 Tahun 1998 tentang Perubahan Atas Undang-Undang Nomor 7 Tahun 1992, selanjutnya disebut dengan Undang-Undang Perbankan. Di dalam undang-undang tersebut, "kredit" adalah penyediaan uang atau tagihan yang dapat dipersamakan dengan itu berdasarkan persetujuan atau kesepakatan pinjam meminjam antara bank dengan pihak lain yang mewajibkan pihak peminjam untuk melunasi hutangnya setelah jangka waktu tertentu dengan pemberian bunga. ${ }^{23}$

Dari definisi-definisi mengenai kredit di atas, maka dapat dikatakan bahwa kredit memiliki unsur-unsur pokok sebagai berikut: ${ }^{24}$

a) Kepercayaan, adanya keyakinan dari kreditur atas prestasi yang diberikan pada nasabah debitur yang akan dilunasi sesuai dengan waktu yang telah diperjanjikan. ${ }^{25}$ b) Tenggang Waktu, yaitu suatu masa yang memisahkan antara pemberian prestasi dengan kontraprestasi yang akan diterima pada masa yang akan datang. Dalam unsur waktu ini, terkandung pengertian nilai agio dari uang, yaitu uang yang ada sekarang lebih tinggi nilainya dari uang yang akan diterima di masa mendatang. ${ }^{26}$

c) Degree of risk, adanya risiko yang mungkin akan terjadi selama jangka waktu peminjaman kredit, sehingga untuk menutup kemungkinan kerugian yang muncul dari adanya wanprestasi, sudah sewajarnya bila diperjanjikan sebelumnya diantara bank dengan nasabah debitur mengenai adanya suatu jaminan/agunan. ${ }^{27}$

d) Prestasi, adanya objek perjanjian tertentu berupa prestasi dan kontraprestasi pada saat tercapainya kesepakatan perjanjian pemberian kredit antara bank dengan nasabah debitur. Prestasi yang dimaksud disini adalah dalam bentuk pemberian uang. ${ }^{28}$ Begitu juga halnya dengan kontra prestasi yang berupa uang lebih/bunga sebagai imbal jasa terhadap bank yang telah bersedia untuk meminjamkan sejumlah uang kepada nasabah debitur. ${ }^{29}$

Bertitik tolak dari pendapat di atas, maka dapat dikemukakan bahwa selain unsur kepercayaan tersebut, dalam permohonan

21 Suharno, Analisa Kredit, (Jakarta: Djambatan, 2003), hlm. 1.

22 O.P. Simorangkir, Seluk Beluk Bank Komersial, (Jakarta: Aksara Persada Indonesia, 1998), hlm. 91.

23 Undang-Undang Nomor 10 Tahun 1998 tentang Perubahan Atas Undang-Undang Nomor 7 Tahun 1992 tentang Perbankan, Pasal 1 butir 11.

24 Rachmadi Usman, Aspek-Aspek Hukum Perbankan di Indonesia, cetakan kedua, (Jakarta: Gramedia Pustaka Utama, 2003), hlm. 238.

25 Thomas Suyatno, et al., Dasar-dasar Perkreditan, Ed. 3., hlm 15.

26 Hemansyah, Hukum Perbankan Nasional, (Jakarta: Prenadamedia, 2014), hlm. 59.

27 Ibid., hlm. 59.

28 Muchdarsyah Sinungan, Kredit: Seluk Beluk dan Teknik Pengelolaan (b), (Jakarta: Yagras, 1980), hal. 13.

29 Thomas Suyatno, et al., Dasar-dasar Perkreditan, Ed. 3., hlm 13. 
dan pemberian kredit juga mengandung unsur lain, yaitu unsur waktu, unsur risiko, dan unsur prestasi.

Kegiatan perbankan utamanya adalah menghimpun dan menyalurkan dana. Salah satu kegiatan utama itu adalah bentuk kredit kepada masyarakat dan pengusaha. Keuntungan utama bisnis perbankan adalah selisih antara bunga dari sumber-sumber dana dengan bunga yang diterima dari alokasi dana tertentu. Bagi para pihak (masyarakat dan pengusaha) sebagai penerima kredit diharapkan memperoleh nilai tambah untuk dapat mengembangkan usahanya agar mereka lebih maju. ${ }^{30}$

Untuk melakukan hal tersebut, dalam dunia perbankan, kredit sendiri memiliki beberapa ragam berdasarkan ciri-ciri masing-masing. Pertama, berdasarkan jangka waktunya dikenal kredit jangka pendek, menengah, dan panjang. ${ }^{31}$ Sebagai contoh dari kredit jangka pendek adalah kartu kredit, sedangkan jangka menengah seperti kredit kendaraan bermotor, dan kredit jangka panjang seperti tambahan modal dalam rangka ekspansi usaha. Kedua, menurut cara pemakaiannya dikenal kredit sekali saja (Aflopend), kredit rekening koran, kredit berulang-ulang, kredit bertahap dan kredit tiap transaksi. ${ }^{32}$ Sedangkan Ketiga, berdasarkan tujuan penggunaannya terdapat kredit investasi, dan kredit modal kerja, kredit konsumsi. ${ }^{33}$ Kemudian pada dasarnya setiap jenis atau ragam kredit tersebut wajib dijalankan oleh perbankan dengan hati-hati (prinsip kehati-hatian). Prinsip kehati-hatian (prudent) ini adalah salah satu akibat dari esensi kredit itu sendiri yaitu kepercayaan dalam suatu pemberian kredit juga sebagai perwujudan dari prinsip prudent banking dari seluruh kegiatan perbankan.

Undang-Undang Nomor 23 Tahun 1999 tentang Bank Indonesia jo.UndangUndang Nomor 23 Tahun 2004 jo.UndangUndang Nomor 6 Tahun 2009 dengan tegas menyebutkan pengawasan terhadap urusan kredit. Berdasarkan kewenangan pengawasan oleh Bank Sentral ini, maka Bank Sentral menetapkan pula batas maksimum pemberian kredit (legal lending limit) terhadap individu atau kelompok peminjam tertentu, sesuai dengan apa yang disebutkan dalam Pasal 11 Undang- Undang Perbankan Nomor 7 Tahun 1992. ${ }^{34}$ Disamping itu pula, juga dengan tujuan penegakan prinsip kehati-hatian ini, regulasi tentang perbankan akan diperketat. Sehingga akhirnya dunia perbankan merupakan salah satu bidang yang sangat heavily regulated.

Demikian pula dengan keharusan adanya jaminan hutang dalam setiap pemberian kredit sebenarnya juga mempunyai tujuan agar kredit diluncurkan secara hati-hati, sehingga ada jaminan bahwa kredit yang bersangkutan akan dibayar kembali oleh pihak debitur. Jaminan dalam kegiatan perkreditan dibedakan menjadi dua yaitu jaminan utama dan jaminan tambahan. Jaminan utama kredit adalah berupa kelayakan dari proyek atau usaha itu sendiri, berbeda dengan jaminan

Suharno, Analisa Kredit, hlm. 2.

Muhammad Djumhana, Hukum Perbankan di Indonesia, (Bandung: PT. Citra Aditya Bakti, 2006), hal. 487.

Munir Fuady, Hukum Perkreditan Kontemporer, (Jakarta:Citra Aditya Bakti, 1996), hlm. 15.

Ibid., hlm. 18.

Undang-Undang Nomor 10 Tahun 1998 tentang Perubahan Atas Undang-Undang Nomor 7 Tahun 1992 tentang

Perbankan, Pasal 11. 
tambahan yaitu dapat berupa fixed assets dan/atau tidak bergerak. ${ }^{35}$

Dalam hal ini menurut Pasal 8 UndangUndang Perbankan Nomor 7 Tahun 1992, maka bank wajib mempunyai keyakinan akan kesanggupan debitur untuk melunasi kreditnya. Selanjutnya penjelasan resmi atas Pasal 8 tersebut menegaskan bahwa setiap bank harus memperhatikan prinsip-prinsip perkreditan yang sehat dan harus yakin akan kemampuan debitur untuk melunasi hutangnya agar memperoleh keyakinan tersebut. Bank yang bersangkutan harus pula melakukan penilaian dengan seksama atas watak, kemampuan, modal, agunan, dan prospek usaha debitur. Penilaian tersebut kemudian dikenal dengan nama 5 C's of Credit atau Prinsip $5 \mathrm{C}$ dalam kredit yang adalah singkatan dari unsur-unsur Character (Kepribadian), Capacity (Kapasitas), Capital (Modal), Condition of Economy (Kondisi Ekonomi), Collateral (Agunan) sebagai unsur yang harus ada dalam setiap pemberian kredit.

Terkait dengan salah satu jenis kredit yaitu Kartu Kredit dalam rangka memenuhi prinsip $5 \mathrm{C}$ tersebut, Secara khusus Bank Indonesia mengeluarkan Surat Edaran mengenai Alat Pembayaran Menggunakan Kartu (APMK) yang merupakan peraturan pelaksanaan dari PBI Nomor 14/2/PBI/2012 tanggal 6 Januari 2012 tentang Perubahan Atas PBI Nomor 11/11/PBI/2009 tentang penyelenggaraan kegiatan APMK. Surat ini dimaksudkan untuk meningkatkan penerapan aspek kehatihatian untuk dapat melihat prinsip $5 \mathrm{C}$ yang sebelumnya disebutkan, aspek perlindungan konsumen, dan aspek peningkatan standar keamanan teknologi APMK itu sendiri. Hal ini ditujukan untuk pemberian kartu kredit yang dilakukan oleh penerbit kartu kredit, dimana mereka diwajibkan untuk menerapkan kehatihatian dalam manajemen risiko kredit, antara lain: ${ }^{36}$

a) Batas usia minimum calon pemegang kartu kredit, pemegang kartu kredit utama adalah 21 tahun atau telah kawin sedangkan pemegang kartu kredit tambahan adalah 17 tahun atau telah kawin.

b) Batas minimum penghasilan calon pemegang kartu kredit adalah Rp3 juta per bulan.

c) Batas maksimum plafon kredit yang diberikan kepada satu orang pemegang kartu kredit secara kumulatif adalah sebesar 3 (tiga) kali penghasilan per bulan.

d) Batas maksimum jumlah penerbit kartu kredit yang dapat memberikan fasilitas kartu kredit kepada seorang pemegang kartu kredit adalah sebanyak 2 (dua) penerbit kartu kredit saja.

e) Persentase pembayaran minimum yang harus dibayarkan oleh pemegang kartu kredit adalah sebesar $10 \%$ dari total tagihan. Namun hal ini tidak berlaku bagi pemegang kartu kredit yang memiliki minimum penghasilan sebesar Rp10 juta per bulan.

Kredit pada dasarnya adalah sebuah perjanjian pokok (prinsipil) yang bersifat riil.

35 Suharno, Analisa Kredit, hlm. 40.

36 Peraturan Bank Indonesia tentang perubahan atas Peraturan Bank Indonesia Nomor 11/11/PBI/2009 tentang penyelenggaraan kegiatan alat pembayaran dengan menggunakan kartu, PBI No. 14 / 2/PBI/ 2012, Pasal 15. 
Riil disini berarti bahwa terjadinya perjanjian kredit ditentukan oleh penyerahan uang oleh bank kepada nasabah debitur. Dilihat dari bentuknya, umumnya perjanjian kredit perbankan menggunakan bentuk perjanjian baku (standard contract). ${ }^{37}$ Berkaitan dengan itu, memang dalam praktiknya perjanjiannya telah disediakan oleh pihak bank sebagai kreditur sedangkan debitur hanya mempelajari dan memahaminya dengan baik. Menurut Ch. Gatot Wardoyo mempunyai fungsi-fungsi sebagai berikut. ${ }^{38}$

a) Perjanjian kredit berfungsi sebagai perjanjian pokok.

b) Perjanjian kredit berfungsi sebagai alat bukti mengenai batasan-batasan hak dan kewajiban di antara kreditur dan debitur.

c) Perjanjian kredit berfungsi sebagai alat untuk melakukan monitoring kredit.

Sebagai sebuah perjanjian, kredit memiliki kemungkinan untuk terlanggar atau biasa disebut dengan wanprestasi. Namun pelanggaran dalam perjanjian kredit tidak serta-merta langsung diselesaikan ke pengadilan, terdapat beberapa langkahlangkah yang harus ditempuh oleh perbankan dalam rangka menyelesaikan kredit bermasalah. Dalam rangka memenuhi tujuan pembahasan ini yaitu, perbandingan dengan BNPL permasalahan yang paling banyak terjadi pada fasilitas kredit berupa kartu kredit adalah keterlambatan pembayaran. Ancaman sanksi yang diberikan dalam hal keterlambatan adalah denda keterlambatan. Denda keterlambatan pembayaran adalah sejumlah biaya yang dikenakan oleh pihak bank penerbit kepada nasabah pengguna kartu kreditnya akibat adanya keterlambatan pembayaran yang dilakukan oleh nasabah tersebut, dimana bank menerima pembayaran tersebut setelah lewat tanggal jatuh tempo yang telah ditetapkan oleh pihak bank. Artinya, denda ini timbul akibat kelalaian dalam membayar tagihan kartu kredit tersebut.

Secara khusus, Bank Indonesia mengeluarkan aturan terkait dengan pengenaan denda tersebut. Hal ini diterbitkan melalui Surat Edaran (SE) Nomor 14/17/ DASP tahun 2012 mengenai perubahan atas Surat Edaran Bank Indonesia (SE BI) Nomor 11/10/DASP tentang Penyelenggaraan Alat Pembayaran Menggunakan Kartu. Dalam regulasi yang mulai berlaku sejak tanggal 7 Juni 2012 itu, dikatakan bahwa para pemegang kartu kredit yang terlambat membayar tagihan kartu kreditnya akan dikenai denda keterlambatan pembayaran sebesar $3 \%$ dari total tagihan yang bersangkutan pada bulan tersebut, dimana jumlah maksimal denda yang bisa dikenakan oleh pihak bank adalah sebesar Rp150 ribu. Semakin sering menunggak maka nasabah/aktiva tersebut akan semakin memiliki golongan yang buruk, dimulai dari lancar, dalam perhatian khusus, kurang lancar, diragukan hingga macet. ${ }^{39}$

\section{b. Persamaan dan Perbedaan antara Skema Pembayaran Buy Now, Pay Later dan Sistem Kredit Perbankan Konvensional}

Seperti yang telah disebutkan dalam pokok pembahasan sebelumnya, Buy Now, Pay Later

Hemansyah, Hukum Perbankan Nasional, hlm. 71.

Ibid. hlm. 72 .

39 PBI No. 8/2/PBI/2006 tentang Perubahan Atas PBI No. 7/2/PBI/2005 tentang Penilaian Kualitas Aktiva Bank Umum, Pasal 12 ayat (3). 
(BNPL) adalah layanan pinjaman online tanpa kartu kredit yang memungkinkan konsumen membayar suatu transaksi di kemudian hari, baik dengan sekali bayar atau dengan mencicil ${ }^{40}$ sedangkan kredit adalah penyediaan uang atau tagihan yang dapat dipersamakan dengan itu berdasarkan persetujuan atau kesepakatan pinjam meminjam antara bank dengan pihak lain yang mewajibkan pihak peminjam untuk melunasi hutangnya setelah jangka waktu tertentu dengan pemberian bunga. ${ }^{41}$ Dari pemaparan tersebut sekiranya dapat ditemukan kemiripan dari BNPL dan kredit perbankan dikarenakan adanya banyak kesamaan unsur.

Pertama, esensialitas BNPL ataupun kredit perbankan adalah sama-sama kepercayaan. Adanya keyakinan dari kreditur bahwa penerima pinjaman atau debitur akan mengembalikan pinjaman tepat waktu adalah esensi dari BNPL ataupun kredit perbankan. Kedua, unsur jangka waktu yaitu masa yang memisahkan antara pemberian pinjaman dan pengembalian uang pinjaman juga terdapat dalam kedua hal tersebut. Ketiga, adanya potensi risiko sebagai akibat dari jangka waktu yang memisahkan antara pemberian pinjaman dan pengembalian pinjaman terkait gagal bayar atau terlambat mengembalikan pinjaman selalu ada dalam dua hal tersebut. Keempat, unsur terdapat prestasi atau objek kredit (biasanya adalah pinjaman uang) sama-sama menjadi pokok dari BNPL dan kredit perbankan. Selain dari unsur-unsurnya metode atau skema dari BNPL juga sangat mirip dengan salah satu jenis kredit perbankan yaitu kredit jangka pendek terkhusus fasilitas kartu kredit. Berdasarkan Pasal 1 ayat 4 Peraturan Bank Indonesia No.14/2/PBI/2012 tentang Penyelenggaraan Kegiatan Alat Pembayaran Dengan Menggunakan Kartu menyatakan bahwa ${ }^{42}$ :

"Kartu Kredit adalah Alat Pembayaran dengan Menggunakan Kartu (APMK) yang dapat digunakan untuk melakukan pembayaran atas kewajiban yang timbul dari suatu kegiatan ekonomi, termasuk transaksi pembelanjaan atau untuk melakukan penarikan tunai, dimana kewajiban pembayaran pemegang kartu dipenuhi terlebih dahulu oleh acquirer atau penerbit, dan pemegang kartu berkewajiban untuk melakukan pembayaran pada waktu yang telah disepakati baik dengan pelunasan secara sekaligus (charge card) ataupun dengan pembayaran secara angsuran."

Secara skematis dan metodologis BNPL mirip dengan fasilitas kredit perbankan kartu kredit karena fungsinya yang untuk tujuan konsumsi dan jangkanya yang pendek, lebih lanjut model kartu kredit yang sama persis dengan BNPL adalah kartu kredit dengan penarikan kredit tiap transaksi, karena biasanya dalam skema penyelenggara BNPL kredit dilakukan oleh peminjam uang setiap melakukan transaksi.

Ditinjau dari aspek hukum perjanjian, barulah mulai terlihat perbedaan yang mencolok antara kredit perbankan dan BNPL. Kreditperbankan pada dasarnya adalah sebuah perjanjian pokok (prinsipil) yang bersifat riil.

\footnotetext{
$40 \quad$ Undang-Undang Nomor 10 Tahun 1998 tentang Perubahan Atas Undang-Undang Nomor 7 Tahun 1992 tentang Perbankan, Pasal 1 butir 11.

41 "Waspadai Skema Pay Later Yang Malah Menjadi Pain Later", https://www.cigna.co.id/health wellness/waspadaskema-pay-later.

42 PBI No. 14/2/PBI/2012, Pasal 1 ayat (4).
} 
Riil disini berarti bahwa terjadinya perjanjian kredit ditentukan oleh penyerahan uang oleh bank kepada nasabah debitur. ${ }^{43}$ Sedangkan BNPL di Indonesia dikategorikan sebagai perjanjian peer to peer lending yang adalah salah satu fintech dan digolongkan sebagai lembaga keuangan bukan bank. Perjanjian peer to peer lending seperti yang telah disebutkan sebelumnya meliputi perjanjian antara penyelenggara dengan pemberi pinjaman; dan perjanjian antara pemberi pinjaman dengan penerima pinjaman. ${ }^{44}$ Sehingga dapat disederhanakan bahwa dalam kredit perbankan hanya terdapat hubungan hukum antara kedua belah pihak yaitu bank sebagai kreditur dan nasabah bank atau peminjam uang sebagai debitur, sedangkan dalam BNPL terdapat hubungan hukum antara ketiga pihak yaitu penerima pinjaman sebagai debitur, pemberi pinjaman atau penyedia layanan sebagai kreditur, dan fintech company selaku penyelenggara layanan pinjam meminjam uang berbasis teknologi informasi yaitu pihak yang menyalurkan pinjaman dan akan menagih pinjaman. Kebiasaan dalam bisnis BNPL menentukan sendiri juga bahwa terkadang fintech company ini akan menentukan seberapa besar fasilitas serta berbagai ketentuan pinjam meminjam lainnya yang bisa didapat calon debitur. ${ }^{45}$

Perbedaan selanjutnya adalah terkait dengan pelaksanaan prinsip kehati-hatian. Seperti yang telah disebutkan sebelumnya, dalam kredit perbankan prinsip kehati-hatian (prudent) adalah salah satu akibat dari esensi kredit itu sendiri yaitu kepercayaan dalam suatu pemberian kredit. Peraturan yang mengatur mengenai hal tersebut begitu banyak dan ketat. Menurut Pasal 8 UndangUndang Perbankan Nomor 7 Tahun 1992 misalnya, diatur bahwa bank wajib mempunyai keyakinan akan kesanggupan debitur untuk melunasi kreditnya. Selanjutnya penjelasan resmi atas Pasal 8 tersebut menegaskan bahwa setiap bank harus memperhatikan prinsip-prinsip perkreditan yang sehat dan harus yakin akan kemampuan debitur untuk melunasi hutangnya agar memperoleh keyakinan tersebut. Bank yang bersangkutan harus pula melakukan penilaian dengan seksama atas watak, kemampuan, modal, agunan, dan prospek usaha debitur. Penilaian tersebut kemudian dikenal dengan nama 5 C's of Credit atau Prinsip $5 \mathrm{C}$ dalam kredit yang adalah singkatan dari unsur-unsur Character (Kepribadian), Capacity (Kapasitas), Capital (Modal), Condition of Economy (Kondisi Ekonomi), Collateral (Agunan) sebagai unsur yang harus ada dalam setiap pemberian kredit.

Tindak lanjut dari prinsip kehati-hatian tersebut dapat dilihat kemudian dalam pengajuan kredit perbankan, penilaian aktiva kredit perbankan, hingga pengawasan dan penyelesaian kredit bermasalah, yang dalam hal ini terkhusus fasilitas kartu kredit. Pengajuan fasilitas kartu kredit dari debitur diatur secara tegas dalam PBI Nomor 14/2/ PBI/2012 tanggal 6 Januari 2012 tentang Perubahan Atas PBI Nomor 11/11/PBI/2009, yaitu mensyaratkan batas usia, batas minimum penghasilan, batas maksimum kredit, batas maksimum jumlah kartu kredit, dan persentase pembayaran yang harus

43 Hermansyah, Hukum Perbankan Nasional, hlm.71

44 POJK No. 77/POJK.01/2016, Ps. 18.

45 POJK No. 77/POJK.01/2016, Ps. 1 angka 8. Ps. 1 angka 7. Ps. 1 angka 8. 
dibayarkan oleh pemegang kartu kredit. ${ }^{46}$ Hal tersebut dilakukan untuk melihat syarat atau prinsip $5 \mathrm{C}$ dipenuhi atau tidak oleh pengaju fasilitas kartu kredit. terkait dengan penggolongan dan penilaian aktiva kredit diatur dalam Peraturan Bank Indonesia Nomor 8/2/PBI/2006 tentang Perubahan Atas Peraturan Bank Indonesia Nomor 7/2/ $\mathrm{PBI} / 2005$ tentang Penilaian Kualitas Aktiva Bank Umum. Istilah ini adalah istilah yang digunakan untuk menunjukkan penggolongan kredit berdasarkan kolektibilitas kredit seseorang, yaitu dimulai dari lancar, dalam perhatian khusus, kurang lancar, diragukan hingga macet, sehingga bank akan semakin ragu untuk memberikan kredit kepada debitur atau calon debitur yang memiliki kolektibilitas rendah. ${ }^{47}$ Terkait dengan terjadi gagal bayar atau terlambat bayar oleh debitur Secara khusus, Bank Indonesia mengeluarkan aturan terkait dengan pengenaan denda tersebut. Hal ini diterbitkan melalui Surat Edaran (SE) Nomor 14/17/DASP tahun 2012 mengenai perubahan atas Surat Edaran Bank Indonesia (SE BI) Nomor 11/10/DASP tentang Penyelenggaraan Alat Pembayaran Menggunakan Kartu. Dalam regulasi tersebut, dikatakan bahwa para pemegang kartu kredit yang terlambat membayar tagihan kartu kreditnya akan dikenai denda keterlambatan pembayaran sebesar 3\% dari total tagihan yang bersangkutan pada bulan tersebut, dimana jumlah maksimal denda yang bisa dikenakan oleh pihak bank adalah sebesar
Rp150 ribu. ${ }^{48} \mathrm{Hal}$ tersebutlah kemudian yang menjadikan perbankan disebut sebagai salah satu bidang yang sangat heavily regulated.

Di sisi lain aturan mengenai BNPL di Indonesia belum mengenal dan mengatur mengenai prinsip kehati-hatian dan penerapan dari prinsip tersebut. Berkaitan dengan mitigasi risiko misalkan hanya diatur mengenai keharusan perusahaan untuk melakukan mitigasi risiko tanpa merincikan mengenai apa saja yang perlu dilakukan oleh perusahaan dalam rangka memitigasi risiko. ${ }^{49}$

Contoh lain adalah mengenai pengajuan aplikasi, atau penyelesaian kredit bermasalah juga tidak ada pengaturan secara rincinya, dalam arti lain diserahkan kepada masingmasing fintech company. Dalam hal ini contoh yang kamu analisa dalam tulisan ini adalah OVO Paylater, syarat untuk mendapatkan fasilitas OVO Paylater yakni dengan mengisi informasi pribadi, menyetujui syarat dan ketentuan, memberikan foto Kartu Tanda Penduduk (E-KTP) dan menyetujui perjanjian fasilitas pinjaman dengan partner OVO (terlampir di Syarat dan Ketentuan), kemudian proses pengajuan aplikasi OVO PayLater tersebut maksimal 1x24 jam, dan akan diberikan notifikasi pada aplikasi OVO apabila telah selesai diproses. Sehingga proses pengajuan dapat dikatakan lebih tidak berhati-hati dari kredit perbankan dan juga tidak menggunakan prinsip $5 \mathrm{C}$ yang biasanya digunakan bank dalam menyetujui atau tidak menyetujui pengajuan kartu kredit oleh calon

PBI No. 14 / 2 /PBI/ 2012, Ps. 15.

PBI No. 8/2/PBI/2006, Ps. 12 ayat (3)

48 Surat Edaran Bank Indonesia tentang perubahan atas Surat Edaran Bank Indonesia Nomor 11/10/DASP tentang Penyelenggaraan Alat Pembayaran Menggunakan Kartu, SE BI Nomor 14/17/DASP tahun 2012.

49 Indonesia, Otoritas Jasa Keuangan, POJK No. 77/POJK.01/2016, Ps. 21. 
debitur. ${ }^{50}$ Terkait dengan keterlambatan kebijakan OVO payleter juga mengatur sendiri bahwa setelah jatuh tempo, semua tagihan yang belum terbayar akan dikenakan bunga sisa tagihan sebesar $0,1 \%$ setiap harinya dan akan ditagih pada tagihan berikutnya. ${ }^{51}$

Perbedaan terakhir adalah terkait cara mendapatkan keuntungan dari kredit perbankan dan BNPL. Disebutkan dalam definisi diawal bahwa salah satu unsur kredit perbankan menurut UU perbankan adalah adanya bunga. Keuntungan utama bisnis perbankan diambil dari bunga tersebut, atau lebih lengkapnya selisih antara bunga dari sumber-sumber dana dengan bunga yang diterima dari alokasi dana tertentu. Bagi para pihak (masyarakat dan pengusaha) sebagai penerima kredit diharapkan memperoleh nilai tambah untuk dapat mengembangkan usahanya agar mereka lebih maju. ${ }^{52}$ Sedangkan dalam skema BNPL dalam memberikan pinjaman tidak mengenakan bunga atau interest.

Meskipun terdapat kesamaan-kesamaan yang sangat mendasar pada unsur-unsur pokok dan esensial dari kredit perbankan terkhusus fasilitas kartu kredit dan BNPL ternyata status quo di Indonesia saat ini menunjukkan terdapat perbedaan yang mencolok dalam tatanan pengaturan, utamanya karena BNPL adalah salah satu bagian dalam fintech yang merupakan lembaga keuangan bukan bank, kemudian perbedaan paling terasa adalah karena masih minimnya peraturan yang mengatur mengenai prinsip kehati-hatian dan pelaksanaan prinsip kehati-hatian, dan terakhir mengenai cara mendapatkan keuntungan. Perbedaan-perbedaan tersebut kemudian berisiko menimbulkan isu-isu dalam implementasi dari BNPL di Indonesia, hal tersebut yang akan kemudian dibahas dalam bagian selanjutnya.

\section{c. Risiko dan Potensi Isu dalam Implementasi Skema Pembayaran Buy Now, Pay Later}

Berkaitan dengan penggunaan teknologi informasi dan inovasi di sektor jasa keuangan di Indonesia, beragam layanan keuangan yang memanfaatkan teknologi informasi atau telah menjadi hal yang umum di masyarakat, baik yang ditawarkan oleh lembaga keuangan yang diawasi oleh OJK maupun yang ditawarkan oleh perusahaan start-up dan diharapkan dapat berperan sebagai pendukung untuk meningkatkan tingkat inklusi keuangan di Indonesia. Berdasarkan pembahasan sebelumnya, telah ditemukan beberapa perbedaan maupun kesamaan unsur antara skema BNPL dan kredit pada perbankan konvensional. Apabila ditinjau lebih lanjut, khususnya mengenai perbedaan antara kedua mekanisme pinjaman tersebut, maka dapat ditarik kesimpulan bahwa terdapat potential issues berupa risiko hukum maupun risiko keuangan pada skema pembayaran melalui BNPL.

Pertama, pada skema BNPL tidak terdapat Prinsip 5C dalam pemberian pinjamannya. Fintech company selaku Penyelenggara yang akan menentukan seberapa besar fasilitas serta berbagai ketentuan pinjam meninjam

\footnotetext{
50 "Ovo Help Center", https://www.ovo.id/helpcenter/article/360028038351, diakses pada 27 April 2020.

51 Ibid.

52 Suharno, Analisa Kredit, hlm. 2.
} 
lainnya yang bisa didapat calon debitur. Sebagaimana telah diketahui, bahwa unsur $5 \mathrm{C}$ merupakan unsur yang harus ada dalam setiap pemberian kredit. Pada skema BNPL, persyaratan pengajuan yang diberikan terbilang minim, tidak terdapat sistem pengawasan yang komprehensif serta belum ada pengaturan mengenai penilaian aktiva dari calon debitur. Padahal, penilaian mengenai watak, kemampuan, modal, agunan, dan prospek usaha debitur adalah penting dalam suatu perjanjian pinjaman atau kredit. Hal-hal tersebut tentu dapat menimbulkan potensi penilaian yang salah dari Penyelenggara sebagai calon kreditur atas calon debiturnya. Untuk itu, perlu dipertimbangkan lebih lanjut mengenai aspek kehati-hatian oleh fintech selaku pihak Penyelenggara pinjaman dengan skema BNPL agar tidak menimbulkan kerugian pada kedua belah pihak.

Kedua, jika merujuk ke berbagai pemberitaan, Penyelenggara BNPL enggan menggunakan kata utang karena tidak ingin menimbulkan kesan buruk yang melekat di fasilitas pembiayaan yang ditawarkan fintech kepada konsumen selaku calon debitur. Hal ini ini tidak terlepas dari konsep bisnis yang dirancang oleh fintech pay later. Bentuk modifikasi yang paling umum adalah dengan memberikan berbagai kemudahan pada pengajuan pinjamannya. Perusahaan fintech mendapatkan keuntungan dari biaya keterlambatan pembayaran (late fees), biaya penyimpanan akun (account-keeping fees) setiap bulannya, dan biaya pemrosesan (processingfee) untuk setiap pembayaran yang dilakukan oleh Pengguna. Namun, apabila ditinjau lebih lanjut, ketika terjadi tunggakan pembayaran cicilan pinjaman pay later, maka risiko yang dihadapi sebenarnya mirip dengan risiko jika gagal bayar utang kartu kredit dan utang perbankan lainnya. Yakni dengan cara membekukan akun pengguna, denda yang terakumulasi, penagihan secara berkala, hingga adanya risiko penyelesaian melalui jalur hukum. Untuk itu, bagi Pengguna selaku calon debitur harus lebih memperharikan syarat dan ketentuan yang ditawarkan sebelum akhirnya menyepakati perjanjian pinjaman dengan skema BNPL. Lebih lanjut, tidak dapat dipungkiri bahwa dengan munculnya skema pembayaran BNPL yang kini telah ditawarkan pada berbagai platform digital, akan berpotensi memberikan dampak bagi consumer behaviour atau perilaku konsumen, dalam hal ini yaitu Pengguna selaku debitur. Konsumen, terutama yang berasal dari generasi muda, akan cenderung berperilaku konsumtif karena berbagai kemudahan yang diberikan oleh BNPL.

Oleh karena terdapat beberapa potential issues tersebut, baik Penyelenggara, Pemberi maupun Pengguna Layanan BNPL harus tetap berhati-hati dan menyadari adanya risiko hukum maupun risiko keuangan pada implementasi dari skema pembayaran di era digital ini. Sementara itu, Bank Konvensional juga harus terus melakukan transformasi digital pada berbagai layanan yang memudahkan konsumen, sehingga dapat tetap bersaing dengan sehat sekaligus mewujudkan pertumbuhan ekonomi dan inklusi keuangan yang berkelanjutan di Indonesia.

\section{Penutup}

Saat ini, BNPL atau lebih familiar dikenal sebagai Pay Later, tengah menjadi opsi skema pembayaran yang menarik bagi masyarakat yang memiliki anggaran terbatas. BNPL adalah fasilitas keuangan yang memungkinkan 
metode pembayaran dengan cicilan tanpa kartu kredit. Pay Later merupakan layanan pinjaman online tanpa kartu kredit yang memungkinkan konsumen membayar suatu transaksi di kemudian hari, baik dengan sekali bayar atau dengan mencicil. Metode BNPL yang seperti itu menunjukkan kemiripan dan kesamaan dengan unsur-unsur dasar kredit perbankan seperti kepercayaan, jangka waktu, tingkat risiko, dan prestasi dalam bentuk kredit.

Meskipun terdapat kesamaan-kesamaan yang sangat mendasar pada unsur-unsur pokok dan esensial dari kredit perbankan terkhusus fasilitas kartu kredit dan BNPL, ternyata status quo di Indonesia saat ini menunjukkan, terdapat perbedaan yang mencolok dalam tatanan pengaturan. Utamanya karena BNPL adalah salah satu bagian dalam fintech yang merupakan lembaga keuangan bukan bank, kemudian perbedaan lain yang paling terlihat adalah karena masih minimnya peraturan yang mengatur mengenai prinsip kehatihatian dan pelaksanaan prinsip kehati-hatian terkait BNPL, cara mendapatkan keuntungan antara BNPL dan kredit perbankan juga memiliki perbedaan yang nyata.

$\mathrm{Hal}$ ini kemudian yang membuka celah akan berbagai potential issues dari mekanisme skema pembayaran BNPL. Untuk itu, perlu dipertimbangkan lebih lanjut mengenai dibuatnya aturan mengenai aspek kehati-hatian dari fintech dengan skema BNPL ini agar tidak menimbulkan kerugian pada kedua belah pihak. Lebih lanjut, prinsip kehati-hatian harus lebih didorong lagi untuk dilaksanakan dalam kegiatan bisnis BNPL bisa dalam bentuk kebijakan perusahaan ataupun kerangka regulasi yang kuat dan detail agar tidak terjadi permasalahan seperti gagal bayar dalam skala besar yang dapat mengganggu stabilitas ekonomi.

\section{Daftar Pustaka}

\section{Buku}

Asosiasi Fintech Indonesia, Handbook Fintech untuk Keuangan Pribadi (Jakarta: Asosiasi Fintech Indonesia, 2019).

Djumhana, Muhamma. Hukum Perbankan di Indonesia (Bandung: PT. Citra Aditya Bakti, 2006).

Fuady, Munir, Hukum Perkreditan Kontemporer (Jakarta:Citra Aditya Bakti, 1996).

Hemansyah, Hukum Perbankan Nasional (Jakarta: Prenadamedia, 2014).

Simorangkir, O.P, Seluk Beluk Bank Komersial (Jakarta: Aksara Persada Indonesia, 1998).

Sinungan, Muchdarsyah, Kredit: Seluk Beluk dan Teknik Pengelolaan (b) (Jakarta: Yagras, 1980).

Soekanto, Soedjono dan Sri Mamudji, Penelitian Hukum Normatif: Suatu Tinjauan Singkat (Jakarta: Raja Grafindo Persada, 1994).

Suharno, Analisa Kredit (Jakarta: Djambatan, 2003).

Suyatno, Thomas, et al., Dasar-dasar Perkreditan. Edisi ketiga (Jakarta: PT. Gramedia Pustaka Utama, 1994).

Usman, Rachmadi, Aspek-Aspek Hukum Perbankan di Indonesia. Cet. 2 (Jakarta: Gramedia Pustaka Utama, 2003).

\section{Makalah/Artikel/Prosiding/Hasil Penelitian}

Adhitya, Imanuel Wulanata Chrismantianto, "Analisis SWOT Implementasi Teknologi Finansial Terhadap Kualitas Layanan Perbankan di Indonesia," Jurnal Ekonomi dan Bisnis Vol. 20 No. 1 (2017).

Berry A. Harahap, et.al., "Perkembangan Financial Technology Terkait Central Bank Digital Currency (CBDC) Terhadap Transmisi Kebijakan Moneter Dan Makroekonomi," Working Paper Bank Indonesia, No. 2, (2017).

Kotarba, Macin, "New Factors Inducing Inducing Changes in the Retail Banking Customer Relationship Management (CRM) and Their Exploration by the Fintech Industry", Foundations of Management Journal Vol. 8 (2016). 
Nizar, Muhammad Afdi "Financial Technology (Fintech): It's Concept and Implementation in Indonesia," Munich Personal RePEc Archive No. 98486 (2017).

\section{Internet}

Bina Nusantara University Popular Articles, "Apa itu PayLater?," Bina Nusantara University, https://sis.binus.ac.id/2020/01/30/apa-itupaylater/ (diakses 27 April 2020).

Cigna Health \& Wellness, "Waspadai Skema Pay Later Yang Malah Menjadi Pain Later," Cigna Indonesia, https://www.cigna.co.id/healthwellness/waspada-skema-pay-later (diakses 27 April 2020).

Otoritas Jasa Keuangan, "Mengenal Lembaga serta Produk Dan Jasa Keuangan", https:// sikapiuangmu.ojk.go.id/FrontEnd/CMS/ Article/10424 (diakses 25 April 2020).

Otoritas Jasa Keuangan, "Statistik Fintech Lending Periode Februari 2020", https://www.ojk. go.id/id/kanal/iknb/data-dan-statistik/ fintech/Pages/Statistik-Fintech-LendingPeriode-Februari-2020.aspx, (diakses 25 April 2020).

OVO, "OVO Help Center", https://www.ovo.id/ helpcenter/article/360028038351 (diakses 27 April 2020).
OVO, "OVO Help Center", https://www.ovo.id/ helpcenter/article/360028038891 (diakses 27 April 2020).

Taralite, "Disclaimer Risiko", https://www.taralite. com/assets/documents/disclaimer.pdf (diakses 27 April 2020).

\section{Peraturan}

Undang-Undang Nomor 10 Tahun 1998 tentang Perubahan atas Undang-Undang Nomor 7 Tahun 1992 tentang Perbankan

Peraturan Otoritas Jasa Keuangan Nomor 77/ POJK.01/2016 tentang Layanan Pinjam Meminjam Uang Berbasis Teknologi Informasi

Peraturan Bank Indonesia Nomor 14/2/PBI/2012 tentang Perubahan Atas Peraturan Bank Indonesia Nomor 11/11/PBI/2009 tentang Penyelenggaraan Kegiatan Alat Pembayaran Dengan Menggunakan Kartu.

Peraturan Bank Indonesia Nomor 8/2/PBI/2006 tentang Perubahan atas Peraturan Bank Indonesia Nomor 7/2/PBI/2005 tentang Penilaian Kualitas Aktiva Bank Umum.

Surat Edaran Bank Indonesia Nomor 14/17/DASP tahun 2012 tentang perubahan atas Surat Edaran Bank Indonesia Nomor 11/10/DASP tentang Penyelenggaraan Alat Pembayaran Menggunakan Kartu. 